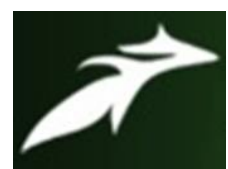

Vijay Yadav et al, Int. Journal of Advances in Agricultural Science \& Technology,

Vol.8 Issue.10, October-2021, pg. 142-147

ISSN: 2348-1358

Impact Factor: 6.057

NAAS Rating: 3.77

\title{
CONSTRAINTS FACED BY RESPONDENTS ON KISAN CREDIT CARD SCHEME AND SEEK THEIR SUGGESTIONS FOR BETTER SERVICES
}

\author{
Vijay Yadav* \\ M.Sc. Ag. (Agricultural Extension and Communication) \\ Prof. (Dr.) Ms. Jahanara** \\ Professor \& Head, Department of Agricultural Extension and Communication, SHUATS \\ Dr. Dipak Kumar Bose**** \\ Associate Professor, Department of Agricultural Extension and Communication, SHUATS \\ DOI: 10.47856/ijaast.2021.v08i10.016
}

\begin{abstract}
The scheme Kisan credit card was started in August 1998 in order to provide timely and hassle free credit for the production requirements of the farmers. The main purpose of the scheme was to meet the production as well as consumption needs of the farmers. The present study was conducted in Soraon block of Prayagraj district of Uttar Pradesh. Ex-post facto research design was followed for the analysis. There are 20 blocks in the selected district out of that Soraon block was selected purposively because the existence of Kisan Credit Card scheme is comparatively more as compared to other blocks. There are 71 villages in the selected block out of that number of 6 villages was selected based on maximum number of farmers involved in KCC scheme. Total number of 120 respondents were selected randomly from 6 villages for the present study The major constraints faced by the respondents are High rate of interest on loan followed by Purpose of availing loan not accepting, Timeliness of credit, Delay by bank side and Duration of loan was very short. It was suggested that Credit limit to be increased considering family expenses, Extent of validity of card up to 5 years, Lower the interest rate, Repayment only after harvest, Flexibility to draw cash and Limit to be fixed on the basis of operational land holding, which will be lead all round development in the research area.
\end{abstract}

Keywords: KCC, Constraints, Suggestions etc. 


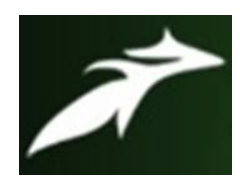

Vijay Yadav et al, Int. Journal of Advances in Agricultural Science \& Technology, Vol.8 Issue.10, October-2021, pg. 142-147

ISSN: 2348-1358

Impact Factor: 6.057

NAAS Rating: 3.77

\section{Introduction}

Nationalized Banks and RRB's introduced the Kisan Credit Card Scheme of NABARD in their areas of operation in 1998-99. In this scheme eligible farmers are provided with a Kisan Credit Card and a passbook or card-cum-pass book. The revolving cash credit facility allows any number of withdrawals and repayments within the limit. This limit is fixed on the basis of operational land holding, cropping pattern and the scale of finance. Sub-limits may be fixed at the discretion of banks. (Kothari, 2015)

The scheme Kisan credit card was started in August 1998 in order to provide timely and hassle free credit for the production requirements of the farmers. The main purpose of the scheme was to meet the production as well as consumption needs of the farmers. It facilitates in providing financial assistance to the farmers to meet their credit needs in relation to production, consumption as well as other allied activities throughout the year as and when required. Credit assistance is required by a farmer for several purposes. This can be for the purpose of cultivation of the crops beginning from making the land cultivable, followed by cultivating the land, sowing, nourishing the crops, using fertilizers and pesticides etc. till the harvest of crops. The model for the scheme was prepared by NABARD for issue of Kisan credit card with consultation of some Introduction 10 major banks and the scheme was circulated by RBI to be adopted by all the banks uniformly. The main aim of the scheme was to seek the problems of farmers regarding inadequate, untimed, uneconomic and short-term credit needs. The scheme provides credit for crop production, ancillary and non-farm activities as well as consumption needs. The scheme was implemented throughout the country with effect from the year 1998-99. (Kaur,2018)

Using the NABARD KCC scheme, the eligible farmers have been issued a Kisan Credit Card or Pass Book. Within the prescribed limit, there can be any number of withdrawals and repayments with the cash credit facility. In order to assess and fix the limit of a farmer, the annual total production credit needs include other auxiliary activities in relation to crop production. Within the due course, even the allied activities and short-term credit needs pertaining to non-farming may also be covered. The limit of a farmer is set on the base of his 


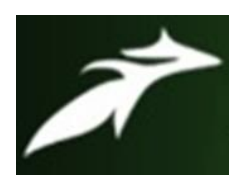

Vijay Yadav et al, Int. Journal of Advances in Agricultural Science \& Technology, Vol.8 Issue.10, October-2021, pg. 142-147

ISSN: 2348-1358

Impact Factor: 6.057

NAAS Rating: 3.77

productive land holding, crop pattern and financial scales and the discretion in fixing these sublimit lies with the banks. The limit carries a validity period of three years and it is also a subject to periodic review. The facility even allows re-scheduling or conversion of credit due to loss to crops in case of natural disaster. On the other hand, the promotional and progressive benefits i.e. incentive for good performance or enhancement of credit limit due to inflation or changes in cropping pattern etc. are also given. (Dhaliwal, 2018)

\section{Research Methodology}

Ex-post facto research design was followed for the present study. Soraon block of Prayagraj district of Uttar Pradesh was selected by purposive sampling for the present study. Total 6 number of villages were selected by random sampling. Total 120 number of respondents were selected for the present study. The data was collected by using the pre structured interview schedule. Data analysis is done through frequency, percentage and Rank distribution using statistical tools.

For calculating percentage, frequency was multiplied by 100 and divided by total number of respondents.

$\mathrm{P}=\mathrm{X} / \mathrm{N} \times 100$

Where, $\mathrm{P}=$ Percentage

$\mathrm{X}=$ Frequency of the respondents

$\mathrm{N}=$ Total number of respondents 


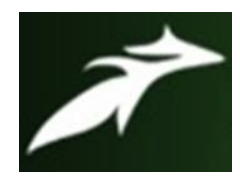

Vijay Yadav et al, Int. Journal of Advances in Agricultural Science \& Technology, Vol.8 Issue.10, October-2021, pg. 142-147

ISSN: 2348-1358

Impact Factor: 6.057

NAAS Rating: 3.77

\section{Results and Discussion}

Table: Distribution of respondents according to their constraints faced by respondents on Kisan Credit Card scheme.

\begin{tabular}{|c|l|c|c|c|}
\hline \multicolumn{1}{|c|}{ Constraints } & \multicolumn{2}{c|}{ Response } \\
No. & & Frequency & Percentage & Rank \\
\cline { 3 - 5 } & & 100 & 83.64 & I \\
\hline 1. & High rate of interest on loan. & 82 & 68.34 & II \\
\hline 2. & Purpose of availing loan not accepting. & 81 & 67.50 & III \\
\hline 3. & Timeliness of credit. & 70 & 66.67 & IV \\
\hline 5. & Duration of loan was very short. & 77 & 64.17 & IX \\
\hline 7. & Huge amount of Procedural formalities. & 72 & 60.00 & VI \\
\hline 6. & Viability of scheme was limited. & 74 & 61.67 & V \\
\hline
\end{tabular}




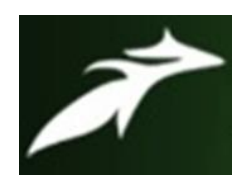

Vijay Yadav et al, Int. Journal of Advances in Agricultural Science \& Technology, Vol.8 Issue.10, October-2021, pg. 142-147

ISSN: 2348-1358

Impact Factor: 6.057

NAAS Rating: 3.77

\begin{tabular}{|c|l|c|c|c|}
\hline 10. & Expansion of agricultural credit. & 69 & 57.50 & XI \\
\hline 11. & Credit limit was not up to the mark. & 52 & 43.33 & XII \\
\hline 12. & Bad behavior of bank employee. & 48 & 40.00 & XIII \\
\hline
\end{tabular}

From the above table It is observed that 83.64 per cent of farmers are facing constraints on High rate of interest on loan (Rank-I) followed by 68.34 per cent of farmers are facing constraints on Purpose of availing loan not accepting (Rank-II), 67.50 per cent of farmers are facing constraints on Timeliness of credit (Rank-III), 66.67 per cent of farmers are facing constraints on Delay by bank side (Rank-IV), 64.17 per cent of farmers are facing constraints on Duration of loan was very short (Rank-V), 61.67 per cent of farmers are facing constraints on Viability of scheme was limited (Rank-VI), 60.00 per cent of farmers are facing constraints on Huge amount of Procedural formalities (Rank-VII), 60.00 per cent of farmers are facing constraints on High repayment schedule (Rank-VIII), 59.17 per cent of farmers are facing constraints on Mode of repayment are difficult (Rank-IX), 57.50 per cent of farmers are facing constraints on Expansion of agricultural credit (Rank-X), 43.33 per cent of farmers are facing constraints on Credit limit was not up to the mark (Rank-XI)and 40 per cent of farmers are facing constraints on Bad behaviour of bank employee (Rank-XII).

\section{Suggestions:}

$>$ Credit limit to be increased considering family expenses.

$>$ Extent of validity of card up to 5 years.

Lower the interest rate.

Repayment only after harvest. 


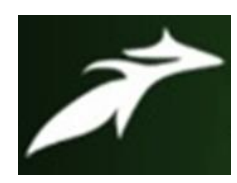

Vijay Yadav et al, Int. Journal of Advances in Agricultural Science \& Technology, Vol.8 Issue.10, October-2021, pg. 142-147

ISSN: 2348-1358

Impact Factor: 6.057

NAAS Rating: 3.77

$>$ Flexibility to draw cash.

Limit to be fixed on the basis of operational land holding.

\section{Conclusion}

The scheme Kisan credit card was started in August 1998 in order to provide timely and hassle free credit for the production requirements of the farmers. The main purpose of the scheme was to meet the production as well as consumption needs of the farmers. The present study was conducted in Soraon block of Prayagraj district of Uttar Pradesh. Ex-post facto research design was followed for the analysis. The major constraints faced by the respondents are High rate of interest on loan followed by Purpose of availing loan not accepting, Timeliness of credit, Delay by bank side and Duration of loan was very short. It was suggested that Credit limit to be increased considering family expenses, Extent of validity of card up to 5 years, Lower the interest rate, Repayment only after harvest, Flexibility to draw cash and Limit to be fixed on the basis of operational land holding, which will be lead all round development in the research area.

\section{References}

[1]. Kothari, P. (2015). A Study on Execution of Kisan Credit Card Scheme In Agricultural Finance With Special Reference to Sbi Mandsaur, Global Journal For Research Analysis, Vol. 4, Issue. 4, ISSN No 2277 - 8160.

[2]. Kaur, H. and Dhaliwal, N.K. (2018). Progress of Kisan Credit Card Scheme in India, Amity Journal of Agribusiness, 3 (1), (26-36). 